\title{
Research and Cooperation Conceptions on the Protection of China-ASEAN Geographical Indications under the Trips Agreement
}

\author{
Xiangjun Kong ${ }^{1,2}$, Yajuan Feng, ${ }^{3, *}$, Yuejuan $\mathrm{Su}^{4}$, Yinghong Kong ${ }^{5}$ \\ ${ }^{1}$ Economic Department, Business and Management Faculty, Guangxi University, China \\ ${ }^{2}$ Guangxi Entry-exit Inspection and Quarantine Bureau, China \\ ${ }^{3}$ Foreign Trade and Business Department, Economic Faculty, Tianjin Polytechnic University, China \\ ${ }^{4}$ Economic Faculty, Guangxi Cadres University of Economics and Management, China \\ ${ }^{5}$ Nanning Vocational and Technical College, China
}

Copyright $\mathrm{C} 2017$ by authors, all rights reserved. Authors agree that this article remains permanently open access under the terms of the Creative Commons Attribution License 4.0 International License

\begin{abstract}
ASEAN is one of the most significant business partners of China. This article analyzes the application of the international agreement on the protection of geographical indications from the perspective of protection and collaboration. It also states the constructive situation between the protection of geographical indications and the administrative system. It asserts that the collaboration under the geographical symbols area of China-ASEAN carries significant stagy meanings in politics, economy and diplomacy and a serious of constructions to establish this collaborative system. What's more, this paper advises the concluding these core contents illustrated as follows: China-ASEAN Expo as a platform for the results of the protection of geographical indications, holding, establishing topic platform of the geographical remarks and registered system of geographical symbols of China-EU.
\end{abstract}

Keywords China-ASEAN, Geographical Indications, Collaboration, Trips Agreement, Protection, Administration

\section{Preface}

The geographical indications came from specific areas and are substances with unique qualities, there're typical intellectual properties. The geographical remarks have become one of the most hot spots in negotiations, particular in some of the bilateral trade negotiations, for example, the intellectual properties agreements related to the trade(for short of Trips agreement).

With the construction of China-ASEAN free trade areas on1st January, 2010 as expected, the economic and trade collaboration between China and ASEAN has been further deepened, the China-ASEAN bilateral collaboration--the protection of the geographical remarks--has gradually arise to a significant topic. During 20th to 21st, May in 2013, the intellectual properties authority of Vietnam came off a seminar in Hanoi, named of "the protection of the East Union's geographical remarks of the market exported and have the abilities to export. This seminar aimed at recommending the register procedures of the Europe Union and the East Unions' geographical indications. The represents from Brunei, Philippines, Singapore, Indonesia, Myanmar, Thailand, Laos and Vietnam, illustrated their own protection campaigns of geographical indications (1). During 28th to 29th, June in 2013, in the 37th APEC intellectual property assembly which associated with a panel of experts, the representative of the General Administration of Quality Supervision, Inspection and Quarantine the People's Republic of China, proposed the "action plan for the promotion of the coordinated development of geographical indications protection many economic and trade development in the Asia Pacific Region"(for short of "action plan"), this propose received an actively response from some countries, such as Thailand, Indonesia and Vietnam, they supported "action plan". (2)

It is the research of geographical indications protection system of the Europe Union countries that Chinese academics forcing on. However, the panel of academics did less about the research of the protection of the geographical indications of the Europe Unions. Zhao Xiaoping (2007) had introduced (3) the protection came from Thailand, Malaysia, Singapore, Indonesia, Vietnam in legal view, Wen Lin (2008) had compared the legal protection system [4] of geographical indications between China and Vietnam. Li Shunde (2010) had studied the developed conditions and the core contents [5] of the geographical indications which came from those six countries including Indonesia, Philippines, Malaysia, Singapore, Vietnam, and Thailand when he 
analyzed the environment of intellectual properties of the ASEAN. Su Yuejuan, Kong Yinghong, Kong Xiangjun (2014) have analyzed the legal protection and administrative system [6-9] in the view of bilateral collaboration deeply came from Indonesia, Vietnam, Thailand, Malaysia. Except of these, nobody had studied the report illustrating the protection and administration of the geographical indications comprehensively and systematically from the perspective of cooperation between China and ASEAN in open literature. Researching the protection and administrative system of geographical indications of the ASEAN systematically carry important meanings to promote the collaboration and protection of geographical indications of China-ASEAN.

\section{The International Convention and Mode for the Protection of Geographical Indications}

\section{(1) The Applicable International Conventions of the Meanings and the Protection of Geographical Indications}

The geographical indication, a name of an address intrinsically, was named as a product.

The Paris Convention for the Protection of industrial Property (for short of Paris Convention), a convention was signed on 20th, March, 1883 and took effect on 6th, July, 1884 by the law community and academic community, was regarded as the first international convention for the protection of the geographical indications. The Paris Convention was the first international agreement regarded the "source ID or name of origin" as the protection object while there were no explicit definitions about geographical indications at that time and the "name of origin" is also another expression of the geographical indications. In the Paris Convention article 1. 2 provides: "the object of protection of industrial property has a patent, unity model, industrial product appearance design, trademark, service mark, manufacture name, source identification or origin name and stop unfair competition. "After that, the Madrid Agreement for the Repression of False or Deceptive Indication of Source on Goods(can be short of Madrid Agreement) administrated by the World Intellectual Property Organization on 14th, April, 1891 has become the first multilateral agreement on the prohibition of false or deceptive source identification of the framework of the Paris Agreement. But the Madrid Agreement has merely involved the source identification issue. The International Convention on the use and nomenclature of the name of the origin of the Central Plains in the cheese industry (can be short of Lisbon agreement) signed in 1951 was not the international agreement of the administration of WIPO. This agreement made a breakthrough firstly in the area of the origin name of cheese although it complied with the spectrum of the European Community(EC), it was the first rule prohibited the use of "type", "class" and other terms. Giving an first explicit definition of the origin name in the international law was signed on 31st, October, 1958and modified in Lisbon Agreement for the protection of the country of origin and its international registration(can be short of Lisbon Agreement ) on 28th, September, 1979. Lisbon Agreement is the first international agreement about the specific rules of origin in the system of the Paris Treaty and it's propose is to provide protection for the name of origin [3]. Lisbon Agreement on the protection of the name of origin to expand the scope of the "class", "style", "like", "copy" or similar names [10] and it made a breakthrough about the regulations in the J Teresa Convention in the prohibition confined by the range of cheese products. Lisbon Agreement submitted that the quality of product of geographical indication, flavor depending on the particular geographical environment and human factors, natural science and technology and the legal protection contacting together for the first time and provided a deeper level of technical basis for the legislation of the geographical indications. The section 1 of article 2 ruled that "the name of origin refers to a geographical name of a nation, an area or a place. It is used only for a product or from an area, its quality or characteristics entirely or mainly depends on the geographical environment, including natural and human factors [11]. Its definition about the geographical indications has an immediate effect on the Trips Agreement. The value of the Lisbon Agreement and its implementation rules for the protection of geographical indications lies in that it has set up a complete system for the name of the origin. In class3, part2, The Trips Agreement, which took effect on 1st, January, 1995, has ruled that the definition of the geographical indications:" A geographical indications is a sign that a product is derived from a member of countries or a region or a location within the region. "Intrinsically, some specific characters or reputation or other features of this product can be attributed to this geographical origin." [12]After the Lisbon Agreement, Trips agreement on the definition of geographical indications is the most clearly defined. Although there are some tiny differences between Lisbon Agreement and Trips Agreement, generally speaking, the meaning of these two definitions is basically the same.

The Trips Agreement is regarded as a watershed of intellectual property protection of geographical indications. Madrid Agreement and Lisbon Agreement, which within the framework of Paris Agreement, have an limited scope and protection furnished by geographical indications, in addition of this, the international protection system of the geographical indication is incomplete. The international conventions that have been concluded before the agreement took effect were considered by the academics to be the convention of traditional intellectual property and the conventions which concluded after the agreement were regarded as the convention of contemporary intellectual property. The Trips Agreement has an extensive binding on the WTO members. In case of dispute, the case in the field of Trips Agreement applies to the WTO dispute settlement procedures [7]. The Trips Agreement furnished a framework for the China-ASEAN collaboration and protection of 
geographical indications.

\section{(2) World Intellectual Property Organization}

The World Intellectual Property Organization (can be short of WIPO) is responsible for the management of many important international agreements relating to the protection of geographical indications. WIPO is an international organization constitution between the governments of the world and it also a specific institution of the United Nations. WIPO is the United Nations third international management, headquartered in Geneva, Switzerland, a total of 186 member countries. In 1967, the management mechanism of Paris Convention and the Berne Convention for the protection of intellectual property rights with established United International Bureau proposed the establishment of WIPO. In July, 1967, in the Stockholm Conference associated with 51 countries signed the Convention on the establishment of the World Intellectual Property Organization and established the WIPO. WIPO management of the union, the development of geographical indications related to the Convention, treaties and agreements are mainly :the Paris Union and the development of the Paris Convention; the Madrid Union and the development of the Madrid Agreement; the Lisbon Union and the development of the Lisbon Agreement and so on. WIPO in the Trips agreement will regarded the geographical indications as the commercial mark which the member states are responsible to protect to.

\section{(3) The Protection Mode of the Geographical Indications}

From the standpoint of legal protection, the protection mode of the geographical indications can be summed up in two: one is the mode of Anti Unfair Competition Law, and the other is from the trademark law mode to the special law mode. In some countries and regions, they adopt two or three kinds of the above three modes, some scholars have used two or more than two kinds of protection mode called mixed mode. From the effect of the legal protection, from Anti Unfair Competition Law, the trademark law mode to the special law mode, the effect of protection is gradually strengthened. Among above modes, the protection of the Anti-Unfair Competition Law is negative and passive; the legal effect of the protection of the special law is the strongest of them. Inside the ASEAN countries, it is not common to see the practice started using the mixed mode, but in China, at the same time, the protection of geographical indications is upgraded to the special law protection mode, and it also retains the trademark law mode of protection of geographical indications with the certification mark. Although they are not mutually exclusive, but there are two or more than two kinds of protection mode at the same time within a country or a region, it will obviously bring trouble to the international cooperation of geographical indications.

\section{The Protection Analysis of Geographical Indications in Members of China and ASEAN}

\section{(1) The Relevant International Organizations and Conventions}

The Uruguay round of trade negotiations, which ended in 1994, reached the Trips agreement, in this round of negotiations, the final agreement decided to establish the World Trade Organization (can be short of WTO) and developed the relevant rules: WTO Member States have to observe all the rules including the Trips Agreement, at the same time, the rules simplify the settlement mechanism of the trade dispute between member countries. WTO established on 1st, January, 1995 and by the end of February1996, the WTO have a total of 159 members. Its members of WTO accounted for over $97 \%$ of the world trade and above this statistic. The last country of ASEAN-Laos joined the WTO formally on 2nd, February, 2013. Till now, ASEAN, associated with 10 countries, and China have become the members of the WTO. The Trips Agreement required all the member states to provide a minimum protection for the intellectual property, including geographical indications, trademarks, etc., and therefore, the Trips Agreement covered all the intellectual property rights of the international agreement which existing now.

Vietnam, one of the ASEAN members, was the first country to join The Convention Establishing the World Intellectual Property Organization and Vietnam has officially became a member of treaty on 2nd, July, 1976; China joined this treaty formally on 3rd, June, 1980. As Myanmar has officially become a member of the treaty on 15th, May, 2001, the 10 ASEAN countries and China signed the treaty all together.

Although the 10 ASEAN countries and China are parities of the convention on intellectual property rights, the convention on the traditional intellectual property rights which have been formed before the Trips Agreement took effect, especially the Madrid Agreement and Lisbon Agreement, which within the Paris Agreement, didn't have a legal effect on every country. Up to February, 2016, the 10 countries-associated with Thailand, Indonesia, Vietnam, Singapore, Philippines, Malaysia, Cambodia, Laos, Brunes and China-have become the members of the Paris Agreement, but only China and Vietnam have signed the Madrid Agreement. With the exception of this, China and the members of the ASEAN-associated with Vietnam, Singapore, Philippines-were all of the members of the Madrid Protocol. It is worth noticing that China and ASEAN 10countries didn't join the Lisbon Agreement and the Agreement of International Organization of Vine and Wine. 
Research and Cooperation Conceptions on the Protection of China-ASEAN

Geographical Indications under the Trips Agreement

Table 1. The general situation of the protection of geographical indications in China and ASEAN countries

\begin{tabular}{|c|c|c|c|c|c|c|c|c|c|c|}
\hline No & Country & $\begin{array}{l}\text { Competent } \\
\text { department }\end{array}$ & $\begin{array}{c}\text { Departmental } \\
\text { membership }\end{array}$ & Legal Basis & Protection mode & $\begin{array}{c}\text { The treaty of WIPO } \\
\text { management }\end{array}$ & $\begin{array}{l}\text { Join WTO } \\
\text { time }\end{array}$ & $\begin{array}{c}\text { Third } \\
\text { country } \\
\text { registration }\end{array}$ & $\begin{array}{l}\text { Duration of } \\
\text { protection }\end{array}$ & $\begin{array}{l}\text { Register } \\
\text { language }\end{array}$ \\
\hline 1 & Thailand & DIP & $\begin{array}{l}\text { Thailand } \\
\text { Ministry of } \\
\text { Commerce }\end{array}$ & $\begin{array}{l}\text { Geographical Indications Protection law } \\
\text { B. E. 2546th(2003); (took effect on 28th, } \\
\text { Apr, 2004); Department of geographical } \\
\text { indications B. E. 2547th(2003); (took } \\
\text { effect on 28th, Apr, 2004) }\end{array}$ & $\begin{array}{l}\text { Special } \\
\text { Law }\end{array}$ & $\begin{array}{l}\text { Became a member of the } \\
\text { Paris Convention on } 2 \mathrm{nd} \text {, } \\
\text { August, } 2008 \text { and } \\
\text { became a member of the } \\
\text { Convention on the } \\
\text { establishment of the } \\
\text { World Intellectual } \\
\text { Property Organization } \\
\text { 25th, December, } 1989\end{array}$ & 1st, Jan, 1995 & Accepted & $\begin{array}{l}\text { Permanently } \\
\text { effective }\end{array}$ & Thai \\
\hline 2 & Indonesia & DGIPR & $\begin{array}{c}\text { Department } \\
\text { of State Law } \\
\text { and Human } \\
\text { rights }\end{array}$ & $\begin{array}{l}\text { Trademark Law }(2001,15 \text { th, took effect } \\
\text { in 1st, August, 2001); } 200751 \text { st } \\
\text { Government regulations on geographical } \\
\text { indications (In } 2007115 \text {, the state } \\
\text { Gazettle, 2007 No. 51st, issued on 4th, } \\
\text { September, } 2007\end{array}$ & $\begin{array}{l}\text { Mixed mode of the } \\
\text { combination of } \\
\text { professional law and } \\
\text { trademark law }\end{array}$ & $\begin{array}{l}\text { Became a member of the } \\
\text { Paris Convention on } \\
\text { 18th, Dec, 1979; and } \\
\text { became a member of the } \\
\text { Convention on the } \\
\text { establishment of the } \\
\text { World Intellectual } \\
\text { Property Organization } \\
\text { 18th, December, 1979 }\end{array}$ & 1st, Jan, 1995 & Accepted & $\begin{array}{l}\text { Permanently } \\
\text { effective }\end{array}$ & Indonesian \\
\hline 3 & Vietnam & NOIP & $\begin{array}{l}\text { Ministry of } \\
\text { science and } \\
\text { Technology }\end{array}$ & $\begin{array}{l}\text { The relevant trade secret, geographical } \\
\text { indications, name of the manufacturer, } \\
\text { and anti-unfair competition for the } \\
\text { protection of industrial property ( } 54 \\
\text { orders); ( } 54 / 2000 / \text { ND-CP law, took } \\
\text { effect on 3rd, October, 2000); } \\
\text { Intellectual Property Law(No. } \\
50 / 2005 / \text { QH11, passed on } 29 \text { th, } \\
\text { November, 2005) }\end{array}$ & $\begin{array}{l}\text { Special } \\
\text { Law }\end{array}$ & $\begin{array}{l}\text { Became a member of the } \\
\text { Paris Convention and the } \\
\text { Madrid Agreement on } \\
\text { 8th, March, 1949; } \\
\text { became a member of the } \\
\text { Convention on the } \\
\text { establishment of the } \\
\text { World Intellectual } \\
\text { Property Organization } \\
\text { 2nd, July, 1976; became } \\
\text { a member of the Madrid } \\
\text { Protocol on 11st, July, } \\
\text { 2006) }\end{array}$ & $\begin{array}{l}\text { 11st, Jan, } \\
2007\end{array}$ & Accepted & $\begin{array}{l}\text { Permanently } \\
\text { effective }\end{array}$ & Vietnamese \\
\hline
\end{tabular}




\begin{tabular}{|c|c|c|c|c|c|c|c|c|c|}
\hline 4 & Singapore & IPOS & $\begin{array}{l}\text { The relevant trade secret, geographical } \\
\text { indications, name of the manufacturer, } \\
\text { and anti-unfair competition for the } \\
\text { protection of industrial property ( } 54 \\
\text { orders); }(54 / 2000 / \text { ND-CP law, took } \\
\text { effect on 3rd, October, } 2000) ; \\
\text { Intellectual Property Law(No. } \\
50 / 2005 / \text { QH11, passed on } 29 \text { th, } \\
\text { November, 2005) }\end{array}$ & $\begin{array}{l}\text { Special } \\
\text { Law }\end{array}$ & $\begin{array}{l}\text { Became a member of the } \\
\text { Paris Convention on } \\
\text { 23rd, February, 1995; } \\
\text { became a member of the } \\
\text { Convention on the } \\
\text { establishment of the } \\
\text { World Intellectual } \\
\text { Property Organization } \\
\text { 2nd, July, 1976; became } \\
\text { a member of the Madrid } \\
\text { Protocol on 31st, } \\
\text { October, 2000) }\end{array}$ & 1st, Jan, 1995 & Accepted & $\begin{array}{c}\text { Not } \\
\text { specified }\end{array}$ & English \\
\hline 5 & Philippines & IPOPHL & $\begin{array}{l}\text { Intellectual property code of the } \\
\text { Philippines (No. } 8293 \text { Republic, took } \\
\text { effect on 1st, Jan, 1998); On Amending } \\
\text { the No. } 8293 \text { method (Intellectual } \\
\text { Property code of the Philippines) of a } \\
\text { number of provisions(Law No. 10372, } \\
\text { took effect on 22nd, March, 2013) }\end{array}$ & Trademark Law & $\begin{array}{l}\text { Became a member of the } \\
\text { Paris Convention on } \\
\text { 27th, Sep1965 and } \\
\text { became a member of the } \\
\text { Convention on the } \\
\text { establishment of the } \\
\text { World Intellectual } \\
\text { Property Organization } \\
\text { 14th, July, 1980 }\end{array}$ & 1st, Jan, 1995 & Not clear & $\begin{array}{c}\text { Not } \\
\text { specified }\end{array}$ & English \\
\hline 6 & Malaysia & MYIPO & $\begin{array}{l}\text { Geographical indications method } \\
\text { (amendment) (took effect on 15th, July, } \\
\text { 2013) instead of revised geographical } \\
\text { indications law } 2000 \text { in 2002: the A1141 } \\
\text { bill took effect on 24th, January, } 2002 \\
\text { and the } 602 \text { bill took effect on 15th, June, } \\
\text { 2000); geographical indications } \\
\text { implementation details 2001[P. U. } \\
\text { (A)247/2001, took effect on 15th, } \\
\text { August, 2001] }\end{array}$ & Special Law & $\begin{array}{l}\text { Became a member of the } \\
\text { Paris Convention and the } \\
\text { Convention on the } \\
\text { establishment of the } \\
\text { World Intellectual } \\
\text { Property Organization } \\
\text { 1st, January, } 1989\end{array}$ & 1st, Jan, 1995 & Accepted & $\begin{array}{l}10 \text { years } \\
\text { renewal }\end{array}$ & English \\
\hline 7 & Cambodia & $\begin{array}{l}\text { Kampuchea } \\
\text { Ministry of } \\
\text { Commerce }\end{array}$ & $\begin{array}{l}\text { Trademark (including geographical } \\
\text { indications) registration and protection } \\
\text { of procedure law (No. } 105 \mathrm{MOC} / \mathrm{SM} \\
\text { 2009, issued on } 18 \text { th, May, 2005) and } \\
\text { behavior regulations of trademark, trade } \\
\text { name law and unfair competition (royal } \\
\text { decree:NS/RKM/0202/006, issued on } \\
7 \text { th, February, 2002) }\end{array}$ & Trademark Law & $\begin{array}{l}\text { Became a member of the } \\
\text { Paris Convention on } \\
\text { 22nd, September, } 1998 \\
\text { and became a member of } \\
\text { the Convention on the } \\
\text { establishment of the } \\
\text { World Intellectual } \\
\text { Property Organization } \\
\text { 25th, July, 1995 }\end{array}$ & $\begin{array}{l}\text { 13th, October, } \\
2004\end{array}$ & Not clear & $\begin{array}{l}10 \text { years } \\
\text { renewal }\end{array}$ & $\begin{array}{l}\text { Khmer } \\
\text { or } \\
\text { English }\end{array}$ \\
\hline 8 & Myanmar & & & $=$ & $\begin{array}{l}\text { Became a member of the } \\
\text { Convention on the } \\
\text { establishment of the } \\
\text { World Intellectual } \\
\text { Property Organization } \\
\text { 15th, May, 2001 }\end{array}$ & 1st, Jan, 1995 & $=$ & $=$ & $=$ \\
\hline
\end{tabular}




\begin{tabular}{|c|c|c|c|c|c|c|c|c|c|}
\hline 9 & Laos & $\begin{array}{l}\text { Lao Ministry } \\
\text { of science and } \\
\text { technology } \\
\text { and } \\
\text { environments }\end{array}$ & $\begin{array}{l}\text { Intellectual property law(Amendment) } \\
\text { (issued on 20th, December, 2011) }\end{array}$ & $\begin{array}{l}\text { Special } \\
\text { Law }\end{array}$ & $\begin{array}{l}\text { Became a member of the } \\
\text { Paris Convention 8th, } \\
\text { October, } 1998 \text { and } \\
\text { became a member of the } \\
\text { Convention on the } \\
\text { establishment of the } \\
\text { World Intellectual } \\
\text { Property Organization } \\
\text { 17th, January, 1995 }\end{array}$ & $\begin{array}{c}\text { 2nd, } \\
\text { February, } \\
2013\end{array}$ & Accepted & $\begin{array}{l}\text { Permanently } \\
\text { effective }\end{array}$ & $\begin{array}{c}\text { Lao } \\
\text { language } \\
\text { (available in } \\
\text { English for } \\
\text { foreign } \\
\text { applications) }\end{array}$ \\
\hline 10 & Brunei & & & $=$ & $\begin{array}{l}\text { Became a member of the } \\
\text { Paris Convention on } \\
\text { 17th, February, } 2012 \text { and } \\
\text { became a member of the } \\
\text { Convention on the } \\
\text { establishment of the } \\
\text { World Intellectual } \\
\text { Property Organization } \\
\text { 21st, April, 1994 }\end{array}$ & 1st, Jan, 1995 & $=$ & $=$ & $=$ \\
\hline \multirow{3}{*}{11} & \multirow{3}{*}{ China } & AQSIQ & $\begin{array}{l}\text { The provisions of the protection of } \\
\text { geographical indications products (July } \\
\text { 15th, 2005) and the work rules for the } \\
\text { protection of geographical indications } \\
\text { products (issued on 21st, May, 2009) }\end{array}$ & Special Law & & \multirow{3}{*}{$\begin{array}{c}11 \text { st, } \\
\text { December, } \\
2001\end{array}$} & Accepted & $\begin{array}{l}\text { Permanently } \\
\text { effective }\end{array}$ & $\begin{array}{l}\text { Chinese } \\
\text { (available in } \\
\text { English for } \\
\text { foreign } \\
\text { applications) }\end{array}$ \\
\hline & & SAIC & $\begin{array}{l}\text { Trademark Law (order No. 6, issued on } \\
\text { 30th, August, 2013, performed on 1st, } \\
\text { May, 2014) and the implementation of } \\
\text { the Trademark Law of the people's } \\
\text { Republic of China (performed on 15th, } \\
\text { September, 2002, 358th of the people's } \\
\text { Republic of China) }\end{array}$ & Trademark Law & & & Accepted & $\begin{array}{l}10 \text { years } \\
\text { renewal }\end{array}$ & Chinese \\
\hline & & $\begin{array}{l}\text { Ministry } \\
\text { Of } \\
\text { Agriculture }\end{array}$ & $\begin{array}{l}\text { Measures for the administration of } \\
\text { geographical indications of agriculture } \\
\text { products (issued on 25th, December, } \\
\text { 2007and performed on 1st, February, } \\
\text { 2008) }\end{array}$ & Special Law & & & Unaccepted & $\begin{array}{l}\text { Permanently } \\
\text { effective }\end{array}$ & Chinese \\
\hline
\end{tabular}

Source of data: The World Intellectual Property Organization network: http://www. wipo.int/wipolex/zh, AQSIQ: http://www. aqsiq.gov.cn/, SAIC: http://sbj.saic.gov.cn

The Ministry of Agriculture of the People's Republic of China: http://www. moa.gov.cn

Relevant information are sorted out. 


\section{(2) The Protection of the Geographical Indication and the Administrative System}

Up to February, 2016, China and the members of the ASEAN, only including Thailand, Vietnam, Singapore, Philippines, Malaysia, Cambodia, and Laos-have established the protection of the geographical indication and the administrative system. Singapore is the first country to carry out special legislation on geographical indications. On 15th, January, 1999, Singapore implemented the geographical indications method(chapter 117B) (No. 44 Law, 1998), this method developed explicit regulations about the definition of geographical indications, the scope of the protection, relief, exceptions and the registration invoked trademark law of geographical indications. On 20th, December, 2011, Laos also issued the Intellectual Property Law (Amendment) and established a basic framework of the protection of geographical indications. Although Myanmar and Brunei are members of the WTO, they haven't established its own system of the protection of geographical indications so far.

In some ASEAN countries, which established the protection of the geographical indications and the management system, Philippines, Cambodia chosen the trademark protection mode, other five countries including Thailand, Vietnam, Singapore, Malaysia, Laos chosen the special law and the protection of trademark by the mixing mode. The situation of China is different from other countries, three departments including AQSIQ, the Ministry of Agriculture, SAIC can accept the registration of geographical indications, as a result, trademark law mode ran parallel to the special law mode. Influenced by the protection mode of the geographical indication, those countries which adopted the special law mode, most of which are clearly defined protection period for an indefinite period of time or not, Malaysia is an exception; Malaysia and Cambodia made an explicit regulation of the protection period of 10years, and allowed the renewal. The protection period of Chinese geographical indications in the special law for permanent; under the trademark law mode, the validity for 10years, but also allowed the renewal.

The propose the protection of geographical indications is not only requires members states to fulfill their obligations to the WTO or other obligations about intellectual property rights convention, more importantly, it also seeks protection for their own or regional characteristic products and industries, therefore, it also be required to allow foreign geographical indications products registered in their own countries when registered national geographical indications in a third country or region at the same time. In the official language of the registration, the general choice is English and native language, refer to Table 1 .

\section{(3) The Standpoint of" the Dispute about Strengthening the Protection of Geographical Indications"}

Under the negotiations about the issue of national geographic indications in ASEAN, there were two different standpoints. In the WTO Doha round of negotiations on the issue of geographical indications, Thailand sided with the camp supported to strengthen the protection to geographical indications, this camp-led by the EU and Switzerland -called "the old world". The "old world camp" claimed that we should strengthen the protection of the geographical indication and asserted that we need to offer the protection of wines and liqueurs and extend them to all the products. At the same moment, the multilateral notification and registration system for wine (which can be intended to all products) shall be legally binding; members are forced to protect geographical indications registered within this system. Different from "the old world", the camp, which resist strengthening the protection of the geographical indication, called "the new world", this camp led by the United States, Japan, Canada, Chile, received supports from Philippines within the ASEAN countries. "The new World" opposed to offer the protection of wine and liqueur and extend them to all the products, meanwhile, they argued that the multilateral notification and registration system for wine(which can be intended to all products) don't have legally binding, members haven't got compulsory obligations to protect the registered geographical indications within the system[3]. Some countries including China, Indonesia, Vietnam, Singapore, Malaysia, Cambodia and Laos didn't clear whether to strengthen the standpoint of geographical indications or not. Some scholars contended that if its own country hasn't got the substantial industry of wine and liqueur and they are unlikely to import these products, they won't furnish higher level of protection for wine and liqueur, these above opinions can affect some ASEAN members such as Malaysia. China is a large country of wine and liqueur production, wine importer, but also a major country of geographical indications resources, strengthen the protection of geographical indications and extend to all products, as a result, it meets the national interests more properly.

\section{(4) The Establishment of Protection System of the Geographical Indication Effected by Legal Elements}

The protection system of geographical indications of China and ASEAN countries established by foreign intellectual property law draws lessons from the EU or the United States of geographical indications protection system more or less. The ASEAN members, with the exception of Thailand, more of them are colonies of foreign countries during a long period of time. Therefore, the legal impact of foreign colonial rule is greater. Among them, Vietnam, Kampuchea, Laos was colonized by French, Indonesia was once a colony of Holland, Singapore, Malaysia, Burma, Brunei was a British colony, Philippines has been ruled by the United States. Influenced by colonial rule, most colonies inherited the colonial rule of the intellectual property rights protection system. Vietnam, Cambodia, Laos, Thailand, formed the intellectual property protection system in the continental law system case basically no legally binding. The legal system of Indonesia is the combination of Holland colonial law national law and case law these three different 
legal systems. Influenced by the Holland Law, the basic legal system of Indonesia is the continent law system. Brunei, Philippines, Singapore, Myanmar, Malaysia inherited the tradition of the common laws of the USA and UK, the case law carries a substantial a weight in the protection system of the intellectual property. Singapore, Malaysia, Myanmar, Brunei followed the British legal system but Philippines followed the American legal system. The Chinese protection system of geographical indication is based on the protection system of geographical indications in France.

\section{The Importance of the Protection and Collaboration of Geographical Indications in China-ASEAN}

\section{(1) China-ASEAN Collaboration in the Area of Geographical Indications Carries a Significant Strategic Significance in the Political, Economic and Diplomatic}

To strengthen the protection and collaboration of geographical indications caters for the interest of members of China-ASEAN. China is kind to its neighbor--The ASEAN and accompanies each other. From China and ASEAN established dialogue relations since 1991, has successfully hosted 10 sessions of the China-ASEAN Expo and established a ministerial consultation system, this system has made remarkable achievements in promoting the development of international trade and mutual political trust, etc. At present, China is the largest trading partner of ASEAN, and ASEAN has become the third largest trading partner of China. ASEAN, the third largest foreign trade deficit region after Chinese Taiwan and South Korea in the Chinese mainland, is the biggest winner after China becoming a member of WTO. From the trade aspect, since 2002, except 2012, the ASEAN Chinese export is greater than China exported to ASEAN; from the international balance of payments, except the $\$ 8500$ millions surplus China to ASEAN in 2002, the overall trade situation kept deficit during a long period of time and China played an important role in promoting the economic development of the ASEANs. In the long run, the balance of international trade is beneficial to live a harmony life with neighbors and to keep a stable condition. Most of the members of the ASEAN full of resources of geographical indications, however, geographical indications mainly including agricultural products, food products and art works. Through the international trade development of geographical indications, find out the actual economic development situation for the ASEAN, is benefit for keeping China-ASEAN's trade balance. In addition, to carry out bilateral cooperation of geographical indications in China-ASEAN in politics and diplomacy is benefit for China and Members of ASEAN display willingness to develop together, make the contact between China and ASEAN countries more actively, coordinate the position of China and
ASEAN members on the issue of geographical indications and other common issues, and it also good for share characteristics of human history, natural geography through its geographical indications trade exhibitions. To strengthen the collaboration in the area of geographical indications, as Wen Jiaobao-the Chinese former prime minister said: "It is benefit for the fundamental interests of sides, regional peace, stability and prosperity."

\section{(2) Strengthening Cooperation between China and ASEAN in the Protection and Management of Geographical Indications is an Objective Requirement to Promote the Economic Development of All Member Countries}

A huge number of geographical indications product resources exist in China-ASEAN in less developed regions, with the development of its characteristic economic in the international trade, it can improve the economic situation where underdeveloped. It is the geographical indication that can narrow economic development level gaps among ASEAN members, economic structures in different countries, and the development balance of product structures and promote the economic development in various of regions. For instance, the Thai fragrant rice enjoys a highly reputation in Chinese market, China's annual imports remain in an amount of 20-30 million tons, meanwhile, bulk Thai rice exports to China pulling the Thailand rice planting and processing industry development.

Bilateral trade between China and ASEAN reached US $\$ 400$ billion 100 million, accounting for $10.4 \%$ of China's total trade with the world in 2012; it is predicted by experts that, in 2015, the bilateral trade between China and ASEAN is expected to exceed $\$ 500$ billion. From the trading volume of China and ASEAN countries, natural resources, primary products, food is still one of the main objects of the bilateral transaction, and agricultural products, food products of geographical indications is the main merchandise of China-ASEAN bilateral trade. Strengthening the protection of geographical indications and collaboration is not only the exterior demand of ASEAN countries in the international trade development but also the objective requirement to promote the domestic economic development.

\section{Plans of Establishing the Protection and Collaborative System of Geographical Indications between China and ASEAN}

\section{(1) Basis and Conditions for Establishing the Protection and Collaborative System of Geographical Indications between China and ASEAN}

The WTO system and Trips Agreement furnishing a legal framework for the protection and collaboration of 
geographical indications between China and ASEAN, so far, China and all the ASEAN members have become members of WTO, WIPO, they have signed some important international intellectual property rights agreements including Trips Agreement, on the establishment of the world Intellectual Property Organization, as the vital important geographical indication within the international intellectual property rights, all of the members have the right to protect these systems and agreements. The Framework agreement on comprehensive economic cooperation between the People's Republic of China and the association of Southeast Asian Nations, which has general constraints on China-ASEAN countries, established products which can enjoy preferential duty reduction; China-ASEAN Free Trade Area rules of origin has established the legal basis for the protection and cooperation of China-ASEAN geographical indications, the both sides can thus continue carrying out relevant cooperation. The AQSIQ and the Thailand Ministry of Commerce signed The Memorandum of cooperation of geographical indications in Beijing and conferred about launching the communication and protection of geographical indications. Both sides of China, Thailand reached an agreement about the successful sign and communication, it was the significant achievement that played an important role of the collaboration of geographical indications in both sides, this achievement not only laid an important foundation for the communications of geographical indications in both sides, but opened a new chapter for the cooperation of the ASEAN geographical indications.

\section{(2) The Main Scope of the Collaborative System and the Protection of Geographical Indications in China-ASEAN}

The main scope of the collaborative system and the protection of geographical indications in China-ASEAN including: Firstly, it is difficult to adapt the current situation of the integrative growth of the free trade area when they are facing the issue of the protection of geographical indications, they need to establish and perfect the communication for the geographical indication on the national level, the information exchange system and the fidelity tracing platform as quickly as possible ;secondly, the interior protection level of geographical indications is unbalanced, most of countries, such as Singapore and Thailand, have established and perfected the protection system of geographical indications while Myanmar and Brunei haven't. Therefore, establishing the technological communication mechanism of the protection of geographical indications and the technological helping mechanism carries significant meanings; Finally, China's protection mode of geographical indications is different from those in ASEAN countries and its applicable laws and technology standards are differ from ASEAN members, there is a mutual recognition of mutual insurance risks, as a result, it is necessary to establish a geographical indications negotiated mechanism for the protection and collaboration in China-ASEAN.

\section{(3) Core Contents of the Protection and Cooperation Mechanism of China-ASEAN Geographical Indications.}

1. China ASEAN Expo as a Platform for the Display of the Achievements of the Protection of Geographical Indications

After the successful hosting of the China-ASEAN Expo for 10 times, the China-ASEAN Expo has become the best platform for Chinese firms to purchase ASEAN products and the recent channel for ASEAN products to expand exports to the Chinese market. Therefore, we can use the China-ASEAN Expo as the platform for displaying geographical indications products, and organize relevant geographical indications products to participate in the exhibition of China -ASEAN Expo. Establishing "products protection expo" and organizing relevant organizations-ASEAN, relevant countries and areas-to display the chambers of commerce, associations and manufacturers is advisable. Moreover, we can invites Chinese provinces, autonomous regions and municipalities to take part in the exhibition. The main contents including three aspects: the general situation of the protection of geographical indications in various countries of between China and ASEAN; products for the protection of geographical indications; the mutual recognition tentative projects of geographical indications in ASEAN and western countries and regions.

\section{Hosting Relevant Seminars and Tribunes about the \\ Protection of Geographical Indications between China and ASEAN Countries}

With the exception of institutional barriers, there are some technical obstacles existing in the protection and cooperation areas of geographical indications in China-ASEAN. Institutional barriers including the constitution of the supervision mechanism of geographical indications, the coordination of the protection modes and the adjustment of the applicable legal system and concerned clauses; technical obstacles including the constitution of the standard system, the unity of the technical obligations; the recognition of the testing technologies of geographical indication products; the confirmation of the third party Inspection institution and the certification authority. Accordingly, it is necessary to host seminars and tribunes under the general framework when both sides reached an agreement on their cooperation, these seminars and tribunes carry three effects as follows: 1, Holding communications and seminars about a sequence of issues and problems on the protection of geographical indications which we met when we carry out tasks; 2 , solving general business cooperation problems of geographical indications which are difficult to deal with through communications and seminars; 3 , opening seminars about common concerned issues of the protection of 
geographical indications, through scholar seminars and tribunes, they can eliminate discrimination $\mathrm{s}$ and sweep all the barriers for the project of the protection and collaboration of geographical indications, as a result, they can promote cooperation to develop more deeply.

3. Establishing the Geographical Indication Fidelity Tracing Platform Based on Modern Information and

Communication Technology, Modern Logistics

Technology

In order to improve the quality of China-ASEAN geographical indications products and create a harmony consumption environment which can provide the necessary technical support to protect personal safety and legitimate rights and interests, one of the major tasks for the protection and cooperation of China-ASEAN geographical indications is to establish the geographical indication fidelity tracing system based on modern information and communication technology, modern logistics technology. For some bulk geographical indications products-such as rice, tea, wine, fruit, liquid products -between China and ASEAN countries, we can use modern information and communication technology, modern logistics technology to establish origin feature recognition database combined with geographic information systems and we can also develop the planting of country of origin, cultivation, breeding, production, processing, transportation, export, import, go to the supermarket and other geographical indications products fidelity tracing platforms.

4. Developing Bilateral Protection and Cooperation of

Geographical Indications and Establishing a Registration

System for the Protection of Geographical Indications of

China-ASEAN

Eventually, the China-ASEAN protection and cooperation of geographical indications is aimed at to establish a international registration for the protection and cooperation of geographical indications, to eliminate technical barriers of the imports of geographical indications, to ensure geographical indications are protected by member states, to reduce the cost of the protection of other countries and to promote the trade facilitation. Though the national submit or ministerial meeting, all the members jointly establish and gradually improve the mechanism of comprehensive including the geographical indication protection in the areas of cooperation, operation system, cooperative regulation, operation management and coordination to realize the strategic objectives of protection and cooperation of geographical indications. In order to establish China-ASEAN protection registration system of geographical indications, it is necessary to clear the principle, scope, condition, content and the dispute settlement mechanism of the protection of geographical indications. Moreover, it is possible to seek a higher international registration protection which based on the China-ASEAN protection mechanism to a sequence of countries or regions, such as the EU and the US.

\section{Acknowledgements}

1) This paper is in the AQSIQ science and technology plan projects which named "Research and cooperation conceptions on the protection of China-ASEAN geographical indications under the Trips Agreement" project, Project No.: 2011IK054

2) This paper is supported by the Scientific Fund Program in 2016 named "Guangxi Key Intellectual Property Area construction and the Regional Layout try pilot sites", Program No.: Gui Science AD16380211

\section{REFERENCES}

[1] Shared registration experiences of geographical indications between EU and ASEAN. World tropical agriculture information, 2013, (7):17-18

[2] Tian Li, the initiative of geographical indications issued by AQSIQ carried a widespread concern from APEC[N], China times, 2013-7-11

[3] Zhao Xiaoping. Research on the legal protection of geographical indications [M]. Beijing: Law press, 2007:133, 220-221.

[4] WenLin. The comparative research on the legal protection of geographical indications in China and Thailand [J]. Journal of Chongqing Technology and Business University: Social Science Edition, 2008, (1):102-105

[5] Li Shunde. Research on intellectual property environment of ASEAN countries [R]. Beijing: The law institute of Chinese Academy of Social Sciences, 2010:91

[6] Su Yuejuan, Kong Yinghong, Kong Lingzi. The Vietnam agricultural products research on the protection system of geographical indications from the perspective of Sino Vietnamese cooperation [J] Journal of southern agriculture, 2014, (1).

[7] Su Yuejuan, Kong Yinghong. The protection system research of Thailand geographical indications under the Trips Agreement [J], Guangxi Social Science, 2014, (2)

[8] Su Yuejuan, Kong Yinghong, Kong Xiangjun. The protection and management protection of Indonesia geographical indications. [J]Journal of Nanning Vocational and Technical College, 2014, 2.

[9] Su Yuejuan, Kong Yinghong, Kong Xiangjun. Bilateral cooperation from the perspective of Malaysia geographical indications protection system. [J]Around Southern Asia, 2014, (4)

[10] Li Zuming. The protection and management of geographical indications [M]. Beijing: Intellectual Property press, 2009:32-33.

[11] The protection of the name of origins and the international registration Lisbon Agreement. [EB/OL]. http://www. viptm. 
cn/display. asp?id=472

[12] Intellectual property agreements related to trade [EB/OL].
1993-12-15http://Wendy. baidu. com/view/EB 1 f54f14693daef5ef73db2. html 